\title{
Rancang Bangun Sistem Informasi Manajemen Aset "SIMA" Berbasis User Centred Design (UCD)
}

\author{
Murdiaty*, Angela, Cindy Aprilia, Nuraina \\ Program Studi Sistem Informasi, STMIK Mikroskil, Medan, Indonesia \\ Email: 1," ${ }^{*}$ murdiaty@ mikroskil.ac.id, ${ }^{2}$ angela.woen@ mikroskil.ac.id, ${ }^{3}$ aprilia.cindy98@gmail.com, ${ }^{4}$ aina_nur36@yahoo.com \\ Email Penulis Korespondensi: murdiaty@mikroskil.ac.id
}

\begin{abstract}
Abstrak-Aset terdiri dari benda tidak bergerak dan benda bergerak, baik yang berwujud (tangible asset) maupun yang tidak berwujud (intangible asset), yang tercangkup dalam harta kekayaan dari suatu instansi, organisasi, badan usaha atau individu perorangan. Pengelolaan aset yang salah akan berakibat buruk bagi perusahaan hingga berdampak kepada kerugian. Pemanfaatan aset tidak bisa dilakukan secara maksimal karena tidak teridentifikasi dengan jelas, sehingga sulit mengetahui mana aset yang masih bisa dipakai atau sudah waktunya harus diganti dan kapan saatnya untuk melakukan perawatan. Aset sangat perlu untuk dikelola dan dimanfaatkan dengan baik demi terjaganya nilai aset tetap tinggi serta mencapai penggunaan dan pemanfaatan aset secara optimal sehingga dapat memberi lebih banyak manfaat bagi perusahaan. Tujuan dari penelitian ini adalah untuk mengembangkan sistem informasi manajemen aset yang bernama SIMA+. Metodologi pengembangan sistem yang digunakan adalah prototyping. Rancangan sistem menggunakan Microsoft Visual Studio 2015 dengan bahasa pemrograman Visual Basic, rancangan output sistem menggunakan Crystal Report, serta penyimpanan data menggunakan Microsoft SQL Server 2014. Hasil dari penulisan ini adalah sistem yang diharapkan memiliki kemampuan menjaga nilai aset, umur pakai aset, serta keamanan aset, meminimalisir kesalahan transaksi pemanfaatan aset dan dapat menyesuaikan data aset yang tercatat pada sistem dan data aset secara fisik.
\end{abstract}

Kata Kunci: Aset; Manajemen Aset; Prototyping; Aset Berwujud; Aset Tidak Berwujud

\begin{abstract}
Assets consist of immovable and movable objects, both tangible and intangible assets, which are included in the fortune of an agency, organization, business entity or individual. The wrong management of assets will be bad for the company so that it is resulting in losses. Utilization of assets cannot be carried out optimally because they are not clearly identified, making it difficult to know which assets can still be used or when it is time to replace them and when it is time to carry out maintenance. Assets really need to be managed and utilized properly in order to maintain high asset value and to achieve optimal use and utilization of assets so as to provide more benefits for the company. The purpose of this research is to develop an asset management information system called SIMA+. The system development methodology used is prototyping. The system design uses Microsoft Visual Studio 2015 with the programming language Visual Basic, the system output design uses Crystal Report, and data storage uses Microsoft SQL Server 2014. The result of this paper is a system that is expected to have the ability to maintain asset value, asset service life, and asset security, minimizing asset utilization transaction errors and can adjust asset data recorded in the system and physical asset data.
\end{abstract}

Keywords: Asset; Asset Management; Prototyping; Tangible Asset; Intangible Asset

\section{PENDAHULUAN}

Manajemen aset merupakan ilmu dan seni untuk memadukan pengelolaan kekayaan yang mencakup proses merencanakan kebutuhan aset, mendapatkan, menginventarisasi, melakukan legal audit, menilai, mengoperasikan, memelihara, membaharukan atau menghapuskan hingga mengalihkan aset secara efektif dan efisien [1] [2]. Aset sendiri adalah barang yang dalam pengertian hukum disebut benda, yang terdiri dari benda tidak bergerak dan benda bergerak, baik yang berwujud (tangible) maupun yang tidak berwujud (intangible), yang tercakup dalam aktiva/kekayaan atau harta kekayaan dari suatu instansi, organisasi, badan usaha atau individu perorangan [2][3].

Aset merupakan sumber daya yang penting bagi suatu perusahaan untuk mendukung operasional dan mencapai tujuan bisnisnya [4]. Adapun yang dimaksud sebagai aset di antaranya: bangunan, tanah, kendaraan, teknologi, peralatan, perlengkapan, mesin, software, hardware, dan benda berharga lainnya. Oleh karena itu, aset sangat perlu untuk diidentifikasi, dikelola dan dirawat dengan baik demi terjaganya nilai aset tetap tinggi dan memiliki usia hidup yang panjang, serta mencapai penggunaan dan pemanfaatan aset secara optimal sehingga dapat memberi lebih banyak manfaat bagi perusahaan [5] [6]. Pengolaan aset yang salah akan berakibat buruk bagi perusahaan hingga berdampak kepada kerugian. Pemanfaatan aset bagi perusahaan juga tidak bisa dilakukan secara maksimal karena tidak terinventarisasi dengan jelas. Umumnya kegiatan dalam inventarisasi aset termasuk pencatatan pengadaan aset, penempatan, mutasi, dan pemeliharaan aset [7].

Dengan adanya suatu sistem informasi manajemen aset yang baik dan lengkap yang tersedia untuk berbagai bentuk perusahaan, diharapkan sistem nantinya akan dapat membantu dalam mengelola, mengamankan serta memperkirakan nilai ekonomis suatu aset dan mempermudah perawatan secara teratur [8]. Untuk dapat mewujudkan hal tersebut terlebih dahulu telah dilakukan eksplorasi beberapa aplikasi aset yang tersedia di internet, dan dari beberapa bentuk aplikasi manajemen aset yang didapat, ditetapkan 2 aplikasi pembanding yang bernama Sixgha dan Sisca. Keduanya adalah software manajemen aset berbayar yang tersedia untuk digunakan pada sebuah perusahaan, namun setelah mempelajari penggunaan dan kegunaan lebih lanjut, masih ditemukan beberapa bagian yang dapat ditambahkan dan perlu untuk dibenahi kembali dari kedua software pembanding tersebut. 
Pada Sixgha tidak terdapat menu menghitung nilai depresiasi aset yang seharusnya termasuk salah satu hal pokok aplikasi manajemen aset, dan pada Sisca tidak memiliki menu pengadaan aset, tidak ada menu peminjaman, dan masih banyak lagi keterbatasan yang ditemukan. Oleh karena itu, penelitian ini bertujuan untuk menyempurnakannnya pada pengembangan kali ini. Aplikasi ini akan diberi nama SIMA ${ }^{+}$(Sistem Informasi Manajemen Aset).

\section{METODOLOGI PENELITIAN}

Metodologi yang digunakan dalam pembuatan rancangan sistem yaitu prototyping. Metode prototyping sebagai suatu paradigma baru dalam pengembangan sistem informasi manajemen, tidak hanya sekedar suatu evolusi dari metode pengembangan sistem informasi yang sudah ada, tetapi sekaligus merupakan revolusi dalam pengembangan sistem informasi manajemen. Metode ini dikatakan revolusi karena merubah proses pengembangan sistem informasi yang lama (SDLC) [9]. Prototyping adalah proses pembuatan model sederhana software yang mengizinkan pengguna memiliki gambaran dasar tentang program serta melakukan pengujian awal [10]-[15]. Pemodelan perangkat lunak juga dimodelkan bersama-sama dengan pengguna.

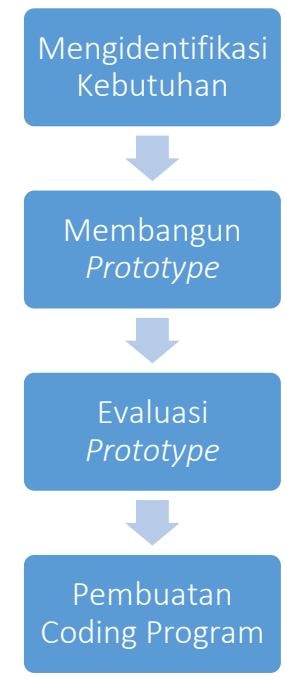

Gambar 1. Tahapan Kegiatan Penelitian

Metodologi prototyping meliputi tahap-tahap sebagai berikut:

1. Mengidentifikasi Kebutuhan

Tahapan pertama pada prototyping bertujuan untuk mengidentifikasi kebutuhan yang diperlukan untuk perancangan prototype Sistem Infromasi Manajemen Aset SIMA ${ }^{+}$, yaitu dengan melakukan perbandingan pada software sejenis yaitu Sixga dan Sisca. Perbandingan tersebut meliputi tampilan, fitur, serta bagaimana prosedur yang digunakan pada kedua software tersebut. Adapun kegiatan pada tahapan ini meliputi:

a) Melakukan analisis software Sixga dan Sisca, menggunakan Flowchart Diagram dan teknik pengumpulan data yang dipilih melalui observasi yaitu penulis melakukan pengamatan terhadap 2 aplikasi pembanding.

b) Melakukan identifikasi kebutuhan fungsional, tools yang digunakan adalah Use Case Diagram, Activity Diagram dan Class Diagram.

2. Membangun Prototype

Membangun prototype sistem SIMA+ dengan membuat perancangan user interface untuk prototype versi pertama yang berfokus pada penyajian kepada pengguna.

3. Evaluasi Prototype

Setelah prototype selesai dibangun maka tahapan selanjutnya yang dilakukan adalah evaluasi prototype versi pertama sistem SIMA+. Evaluasi ini bertujuan untuk mendapatkan informasi penambahan atau pengurangan fitur dalam melengkapi prototype versi pertama yang telah dibuat serta untuk memastikan apakah prototype sudah sesuai kebutuhan atau tidak. Hasil dari evaluasi pada prototype versi yang pertama akan menjadi dasar untuk dikembangkan menjadi prototype versi kedua. Prototype versi kedua akan dievaluasi kembali oleh pengguna, jika terdapat masukan dari pengguna maka prototype versi kedua akan dikembangkan menjadi prototype versi ketiga, dan seterusnya. Tetapi apabila prototype versi kedua menurut pengguna telah memenuhi kebutuhan maka prototype versi kedua ini akan menjadi prototype versi final yang akan dilanjutkan ke tahap berikutnya.

4. Pembuatan Coding Program 
JURNAL MEDIA INFORMATIKA BUDIDARMA

Volume 5, Nomor 2, April 2021, Page 659-668

ISSN 2614-5278 (media cetak), ISSN 2548-8368 (media online)

Available Online at https://ejurnal.stmik-budidarma.ac.id/index.php/mib

DOI 10.30865/mib.v5i2.2663

Prototype versi final yang disepakati akan diterjemahkan ke dalam bahasa pemrograman oleh programmer. Tahapan ini bertujuan untuk merancang, menulis kode program (coding), dan mengatasi kesalahan-kesalahan dari program komputer. Tools yang akan digunakan untuk mengembangkan perangkat lunak adalah Microsoft Visual Studio 2015 serta basis data dirancang dengan menggunakan aplikasi Microsoft SQL Server 2014

\section{HASIL DAN PEMBAHASAN}

\subsection{Identifikasi Kebutuhan Sistem}

Untuk mendapatakan gambaran berbagai fitur dan proses yang akan diterapkan pada aplikasi usulan yang dikembangkan, maka dilakukan observasi terhadap aplikasi sejenis yaitu Sixgha dan Sisca. Hasil observasi terhadap kedua aplikasi tersebut adalah sebagai dasar perumusan kebutuhan sistem informasi manajemen aset yang akan dibangun. Di bawah ini merupakan tampilan home aplikasi Sixgha dan aplikasi Sisca.

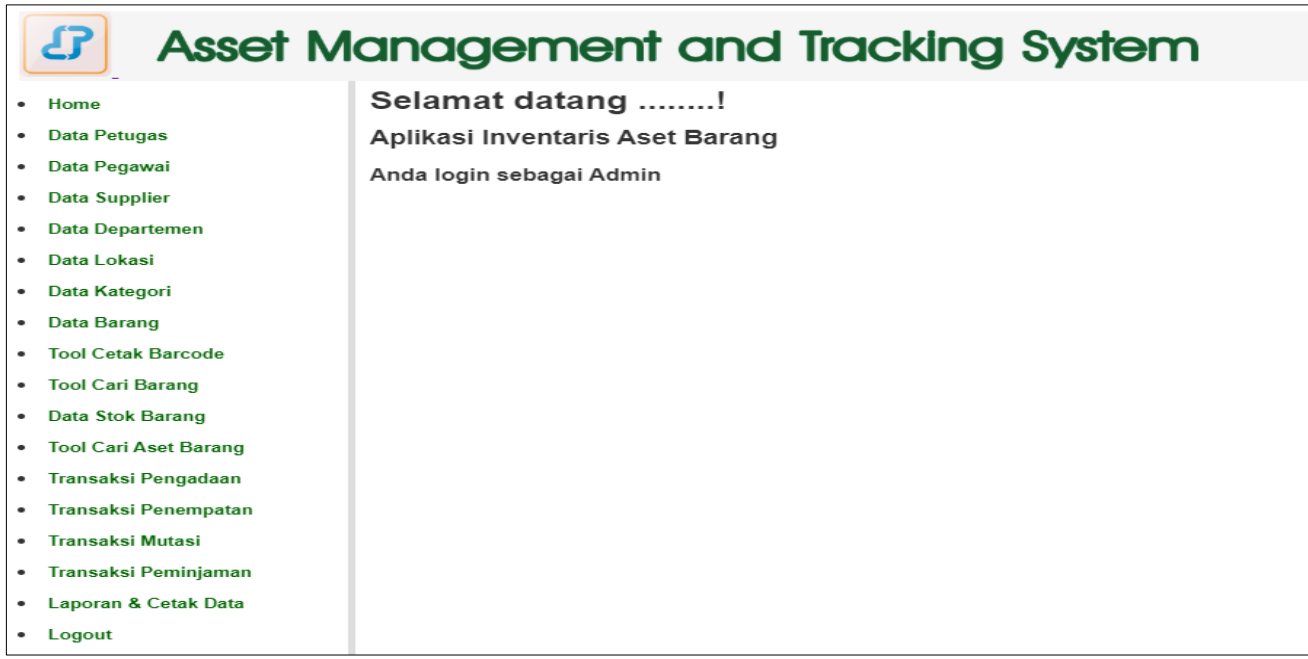

Gambar 2. Tampilan Home Aplikasi Sixgha

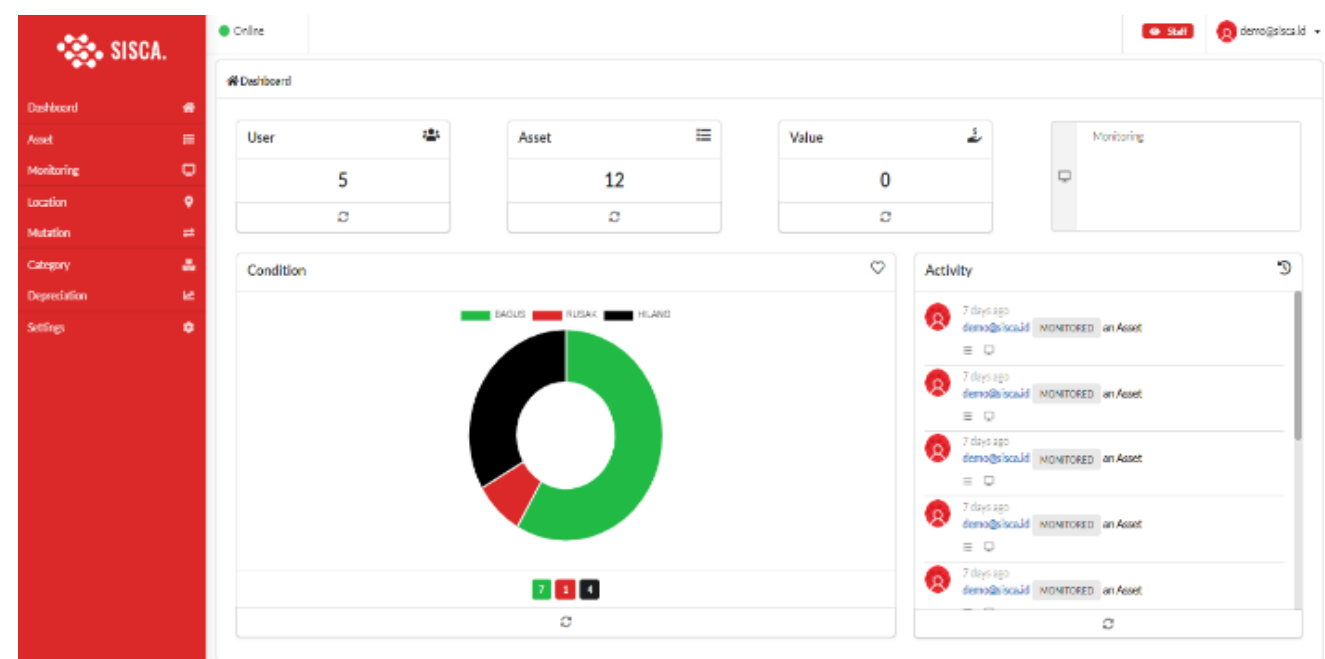

Gambar 3. Tampilan Home Aplikasi Sisca

Tabel di bawah ini menyajikan rekapitulasi fitur yang dimiliki oleh aplikasi Sixgha dan aplikasi Sisca:

Tabel 1. Tabel Rekapitulasi Aplikasi Sixgha dan Sisca

\begin{tabular}{clcc}
\hline No. & \multicolumn{1}{c}{ Fitur } & Sixgha & Sisca \\
\hline 1. & Input Data Pegawai & $\checkmark$ & \\
2. & Input Data Supplier & $\checkmark$ & \\
3. & Input Data Petugas & $\checkmark$ & \\
4. & Input Data Departemen & $\checkmark$ & $\checkmark$ \\
5. & Input Data Kategori Aset & $\checkmark$ & $\checkmark$ \\
6. & Input Data Lokasi & $\checkmark$ & $\checkmark$ \\
7. & Input Data Aset & $\checkmark$ & \\
\hline
\end{tabular}


JURNAL MEDIA INFORMATIKA BUDIDARMA

Volume 5, Nomor 2, April 2021, Page 659-668

ISSN 2614-5278 (media cetak), ISSN 2548-8368 (media online)

Available Online at https://ejurnal.stmik-budidarma.ac.id/index.php/mib DOI 10.30865/mib.v5i2.2663

\begin{tabular}{clcc}
\hline No. & \multicolumn{1}{c}{ Fitur } & Sixgha & Sisca \\
\hline 8. & Upload Foto Aset & $\checkmark$ & $\checkmark$ \\
9. & Transaksi Pegadaan & $\checkmark$ & \\
10. & Transaksi Penempatan & $\checkmark$ & \\
11. & Transaksi Peminjaman & $\checkmark$ & $\checkmark$ \\
12. & Transaksi Mutasi & & $\checkmark$ \\
13. & Maintain Status Aset & & $\checkmark$ \\
14. & Melakukan Perhitungan Depresiasi & & $\checkmark$ \\
15. & Teknologi RFID & $\checkmark$ & \\
16. & Tool Cetak Barcode Reader & $\checkmark$ & $\checkmark$ \\
17. & Penyajian Laporan & & $\checkmark$ \\
18. & Menu Monitoring Aset & & $\checkmark$ \\
19. & Cloud Import System & & $\checkmark$ \\
20. & Settings (Users) & & \\
21. & Dashboard & $\checkmark$ & \\
22. & Pencarian Aset / Asset Tracking & & \\
\hline
\end{tabular}

Dalam mengidentifikasi persyaratan yang dibutuhkan dalam sistem, maka akan digunakan Use Case diagram. Use Case diagram memperlihatkan hubungan yang terjadi antara actor dengan sistem. Penggunaan Use Case diagram juga diterapkan untuk melihat kebutuhan fungsional sistem infromasi manajemen aset SIMA ${ }^{+}$.

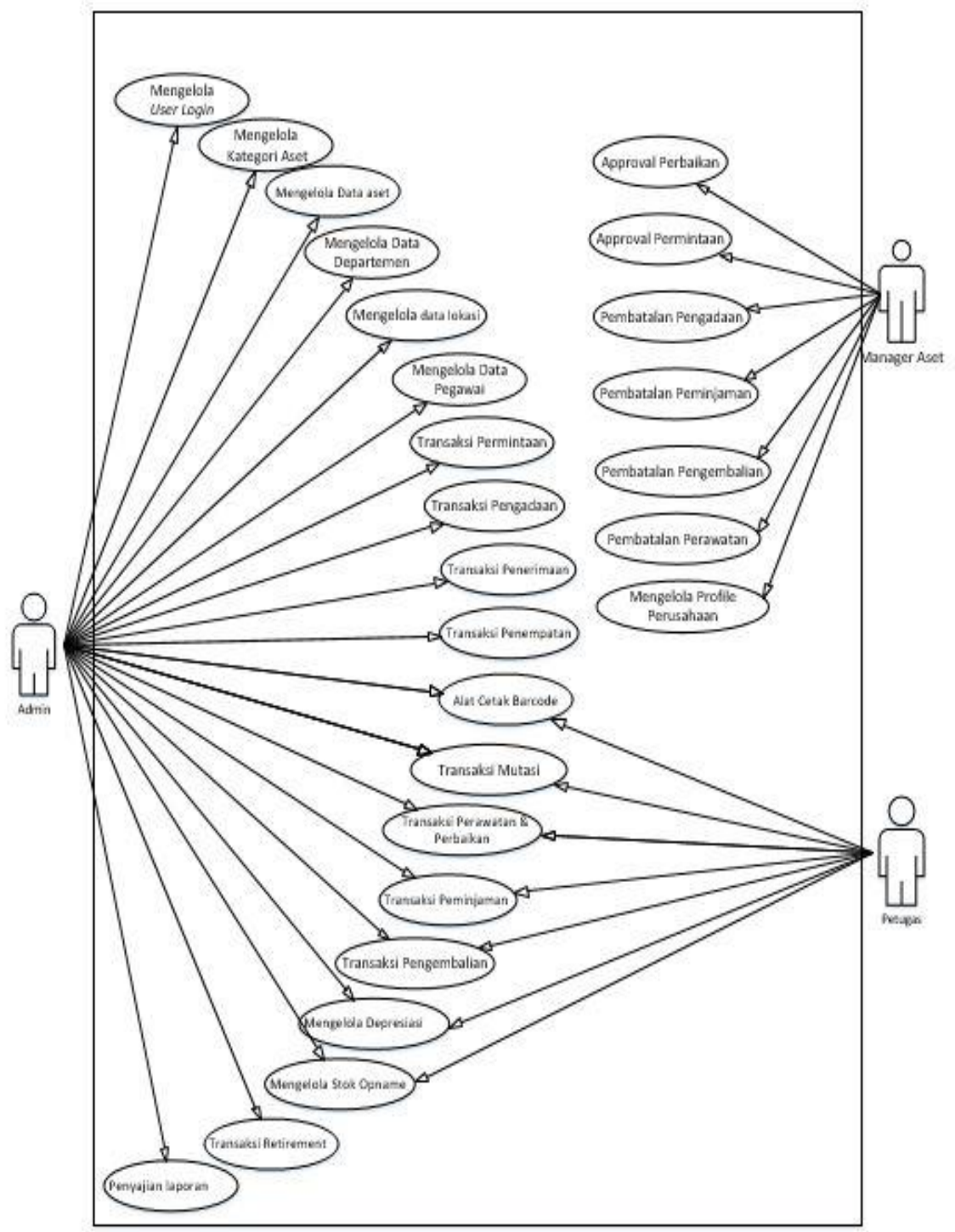

Gambar 4. Use Case Diagram Aplikasi SIMA ${ }^{+}$

Berikut ini adalah salah satu activity diagram dari proses yang terdapat dalam aplikasi $\mathrm{SIMA}^{+}$yaitu proses peminjaman aset: 
JURNAL MEDIA INFORMATIKA BUDIDARMA

Volume 5, Nomor 2, April 2021, Page 659-668

ISSN 2614-5278 (media cetak), ISSN 2548-8368 (media online)

Available Online at https://ejurnal.stmik-budidarma.ac.id/index.php/mib DOI $10.30865 /$ mib.v5i2.2663

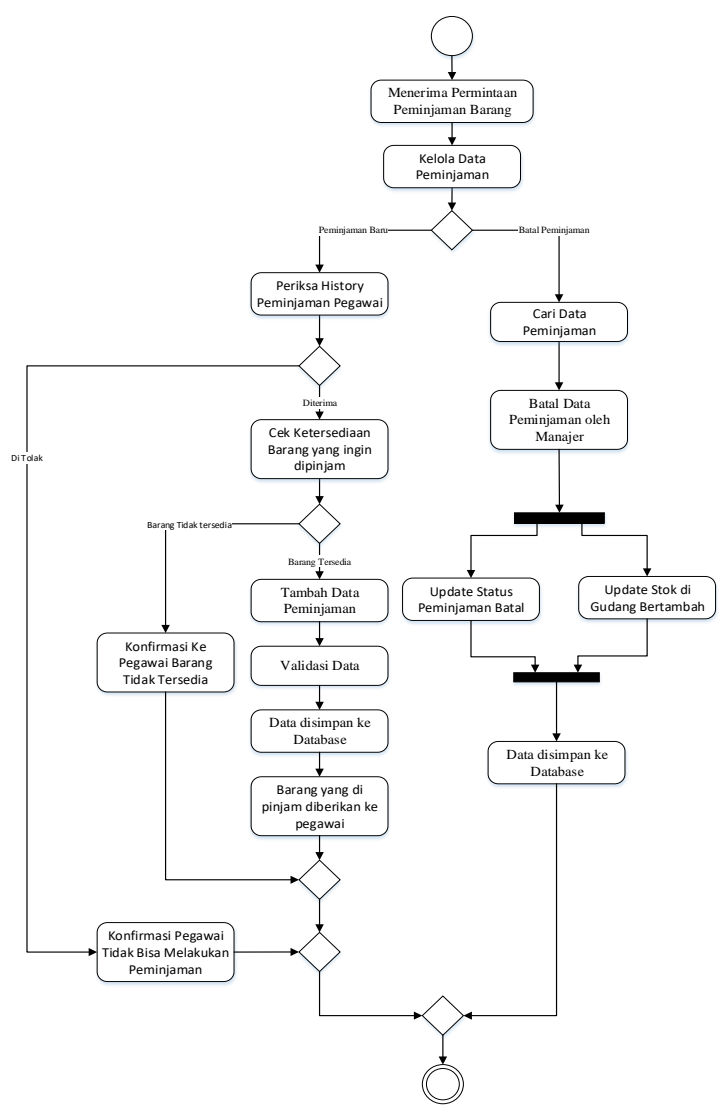

Gambar 5. Activity Diagram Transaksi Peminjaman

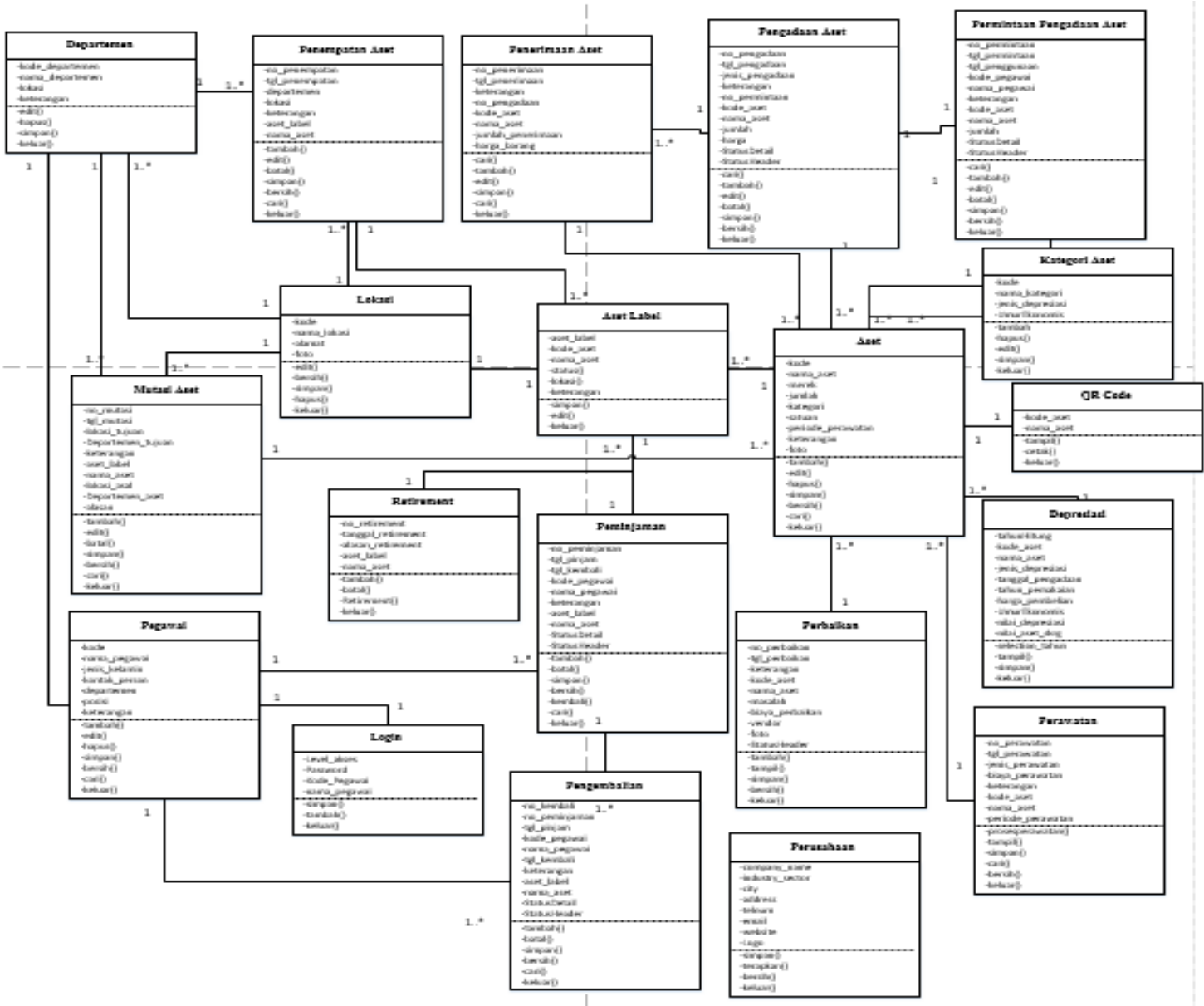

Gambar 6. Class Diagram Aplikasi SIMA ${ }^{+}$

Murdiaty, Copyright (C2021, MIB, Page 663 


\subsection{Membangun Prototype}

Prototype versi pertama yang dibangun terdari dari fitur: tampilan login, tampilan input data pegawai, tampilan input data kategori aset, tampilan input data lokasi, tampilan input data departemen, tampilan input data aset, tampilan menghasilkan aset label, tampilan input data permintaan aset, tampilan input data pengadaan aset, tampilan input data penerimaan aset, tampilan input data penempatan aset, tampilan input data mutasi aset, tampilan input data peminjaman aset, tampilan input data pengembalian aset, tampilan input data perawatan aset, tampilan input data perbaikan aset, tampilan proses depresiasi aset, tampilan cetak barcode aset, tampilan proses penghapusan/pemberhentian (retirement) aset, tampilan mencetak laporan (terdiri dari laporan pegawai, laporan lokasi, laporan departemen, laporan kategori, laporan aset, laporan aset per kategori, laporan aset per lokasi dan laporan pengadaan aset per bulan).

\subsection{Evaluasi Prototype}

Setelah prototype versi pertama dirancang, maka prototype ini ditunjukkan kepada pengguna untuk melihat apakah rancangan yang dibuat telah memenuhi kebutuhan pengguna, apakah terdapat pengisian data yang kurang lengkap atau terdapat fitur baru yang perlu ditambahkan sesuai kebutuhan pengguna. Setelah prototype pertama ditunjukkan kepada pengguna, maka sesuai dengan masukan pengguna, tim melakukan pengembangan untuk prototype versi kedua.

\subsection{Implementasi Program}

Prototype versi kedua merupakan prototype final yang dibangun terdari dari fitur:

1. Tampilan dashboard

2. Tampilan input data master terdiri dari:

a. Master data pegawai, digunakan untuk menginput data pengawai yang akan digunakan dalam transaksi.

b. Master data kategori, digunakan untuk menginput data kategori aset.

c. Master data lokasi, digunakan untuk menginput data lokasi aset.

d. Master data departemen, digunakan untuk menginput data departemen yang dimiliki perusahaan.

e. Master data aset, digunakan untuk menginput data aset. Dalam master data aset terdiri dari aset label yang berfungsi jika 1 aset (misalnya: Printer A) terdiri dari 10 unit, maka masing-masing unit akan memiliki aset label yang berbeda-beda dari unit ke-1 sampai unit ke-10, sehingga aset tersebut dapat dilacak keberadaannya. Aset label dari dicetak dalam bentuk tampilan barcode sehingga dapat ditempelkan pada masing-masing aset.

f. Master data profile perusahaan yang akan menggunakan aplikasi SIMA ${ }^{+}$ini.

3. Tampilan input data transaksi terdiri dari:

a. Transaksi permintaan pengadaan aset, digunakan untuk menginput data permintaan aset baru yang akan dibeli oleh perusahaan.

b. Transaksi pengadaan aset, digunakan untuk menginput data pengadaan aset baru.

c. Transaksi penerimaan aset, digunakan untuk menginput data penerimaan aset baru.

d. Transaksi penempatan aset, digunakan untuk menginput data penempatan aset pada lokasi dan departemen mana dalam perusahaan.

e. Transaksi mutasi aset, digunakan untuk menginput data mutasi atau perpindahan aset dari satu lokasi dan depertemen ke lokasi dan depertemen yang baru.

f. Transaksi peminjaman aset, digunakan untuk menginput data peminjaman aset.

g. Transaksi pengembalian aset, digunakan untuk menginput data pengembalian aset yang telah dipinjam.

h. Transaksi perhitungan depresiasi, digunakan untuk sistem menghitung data penyusutan atau depresiasi aset pada setiap tahun.

i. Transaksi perawatan atau perbaikan aset, digunakan untuk menginput data perawatan aset dan perbaikan aset yang rusak.

j. Transaksi pemberhentian (retirement) aset, digunakan untuk menginput data aset yang akan diberhentikan karena salah satu alasan aset tersebut telah rusak dan tidak dapat digunakan kembali.

4. Tampilan output terdiri dari: tampilan cetak barcode aset label, laporan aset, laporan aset label, laporan stock opname, laporan pegawai, laporan lokasi, laporan departemen, laporan kategori, laporan permintaan pengadaan aset, laporan pengadaan aset, laporan penerimaan aset, laporan penempatan aset, laporan mutasi aset, laporan peminjaman aset, laporan pengembalian aset, laporan perawatan aset, laporan perbaikan aset, laporan depresiasi aset, laporan nilai aset dan laporan pemberhentian (retirement) aset.

Berikut ini merupakan rancangan relasi antar tabel yang digunakan dalam basis data aplikasi SIMA ${ }^{+}$: 
JURNAL MEDIA INFORMATIKA BUDIDARMA

Volume 5, Nomor 2, April 2021, Page 659-668

ISSN 2614-5278 (media cetak), ISSN 2548-8368 (media online)

Available Online at https://ejurnal.stmik-budidarma.ac.id/index.php/mib

DOI 10.30865/mib.v5i2.2663

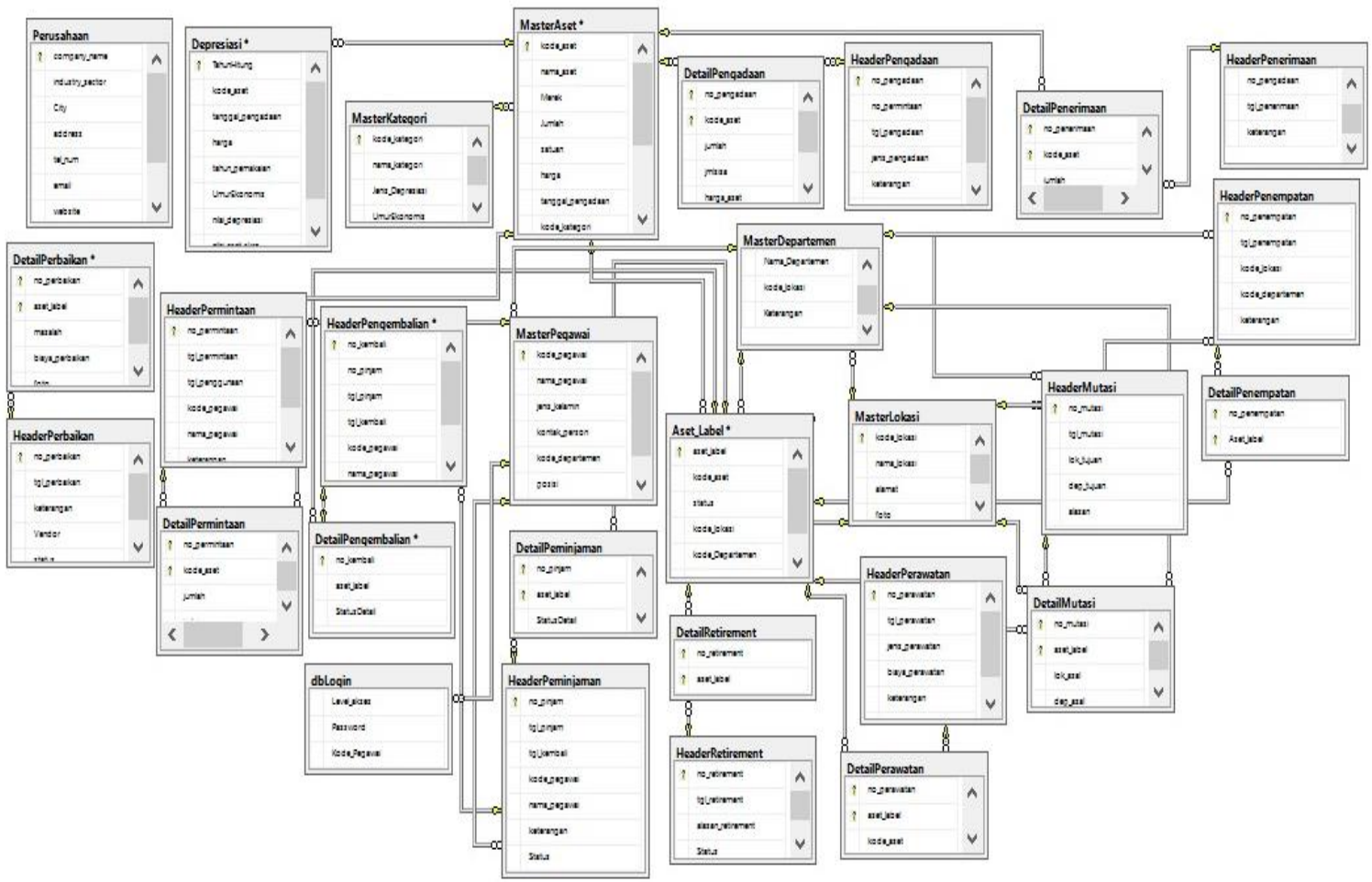

Gambar 7. Relasi Antar Tabel Sistem Manajemen Aset SIMA ${ }^{+}$

Terdapat 3 kategori hak akses dalam Sistem Manajemen Aset SIMA ${ }^{+}$yaitu:

a. Admin, memiliki hak akses penuh terhadap fitur dalam mengelola sistem manajemen aset SIMA+. Admin dapat melakukan create, update, delete, view, serta cetak.

b. Petugas Aset, memiliki keterbatasan dalam melakukan create data dan hanya dapat mengakses beberapa menu yang dijalankan untuk operasional sehari-hari saja.

c. Manajer TI, memiliki kelebihan untuk melakukan persetujan / approval terhadap permintaan, dan perbaikan aset serta dapat mengakses menu laporan.

Berikut ini merupakan beberapa tampilan dari Sistem Manajemen Aset SIMA ${ }^{+}$antara lain:

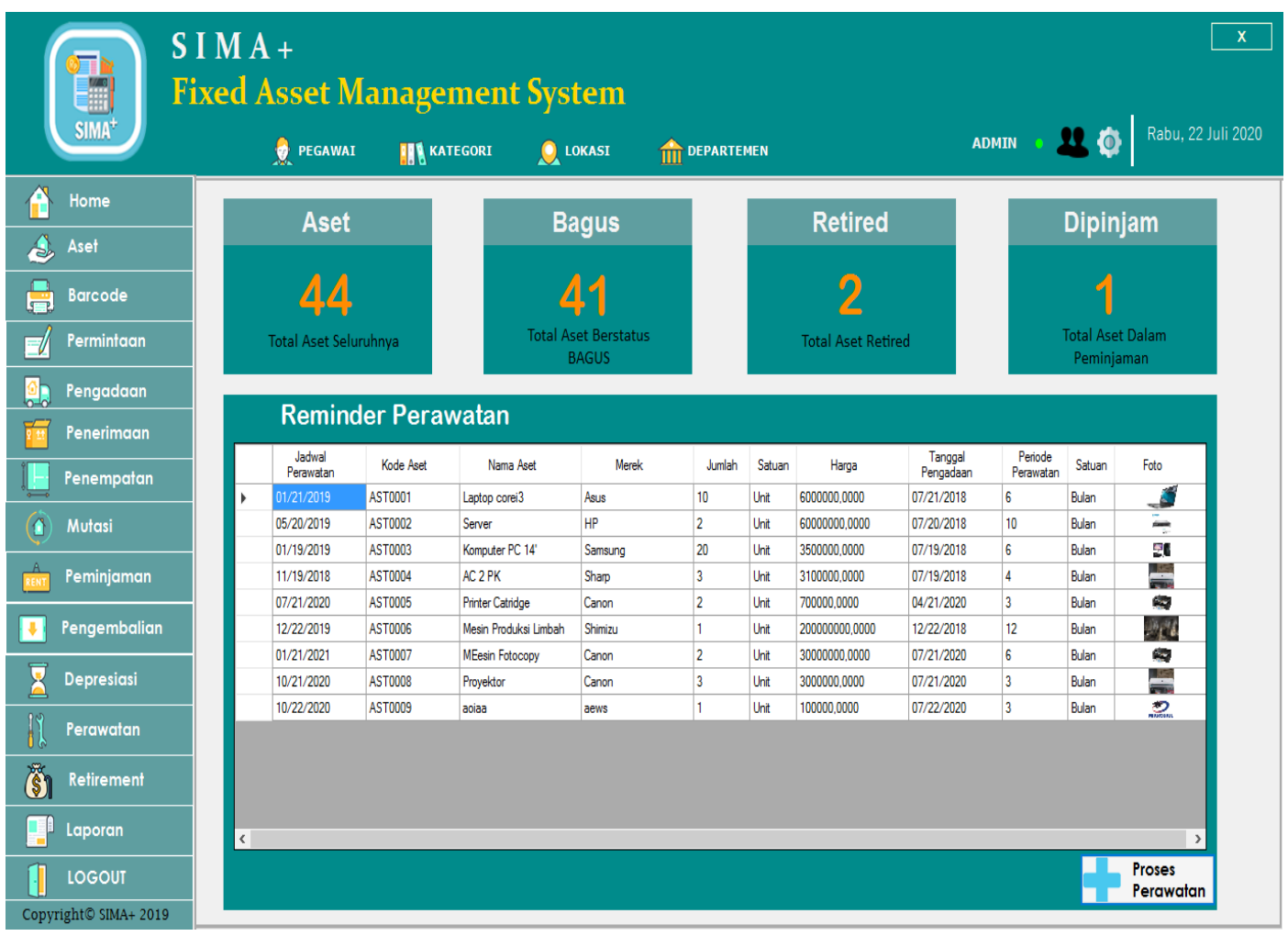

Gambar 8. Tampilan Dashboard Untuk Admin Sistem Manajemen Aset SIMA ${ }^{+}$ 
JURNAL MEDIA INFORMATIKA BUDIDARMA

Volume 5, Nomor 2, April 2021, Page 659-668

ISSN 2614-5278 (media cetak), ISSN 2548-8368 (media online)

Available Online at https://ejurnal.stmik-budidarma.ac.id/index.php/mib DOI 10.30865/mib.v5i2.2663

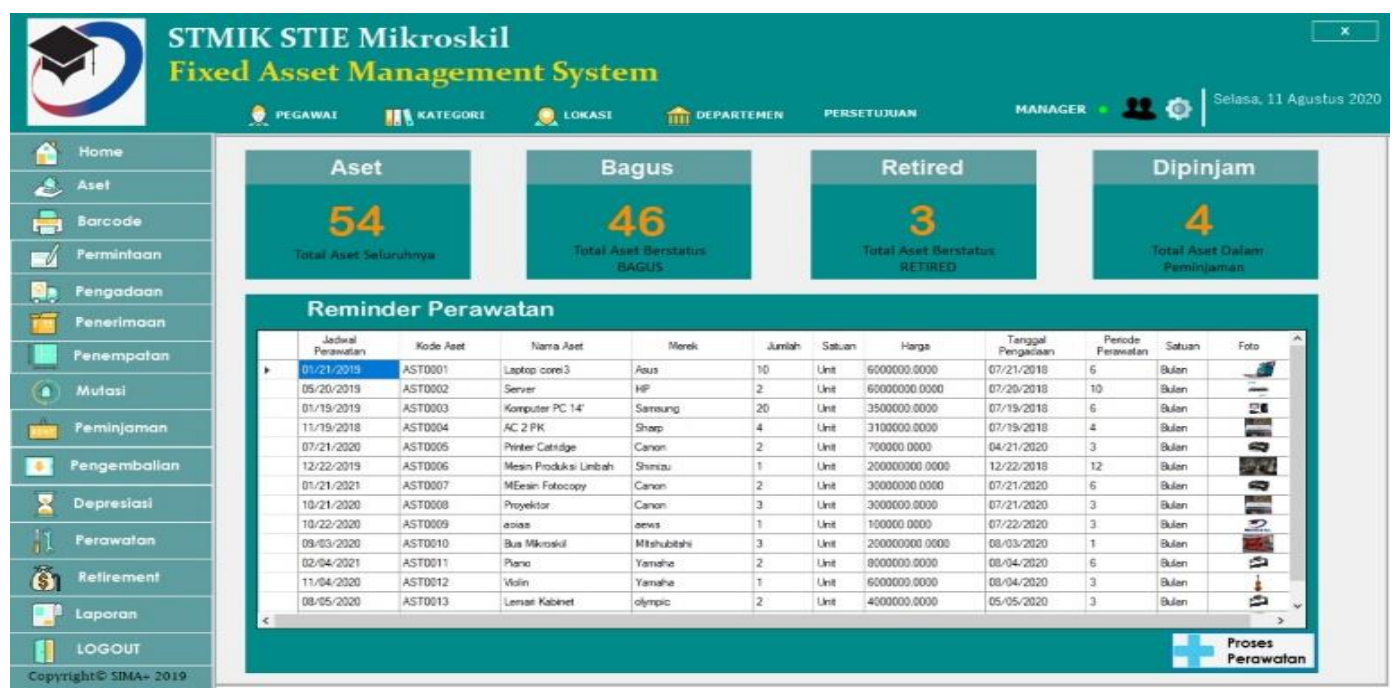

Gambar 9. Tampilan Dashboard Untuk Manajer Sistem Manajemen Aset SIMA ${ }^{+}$

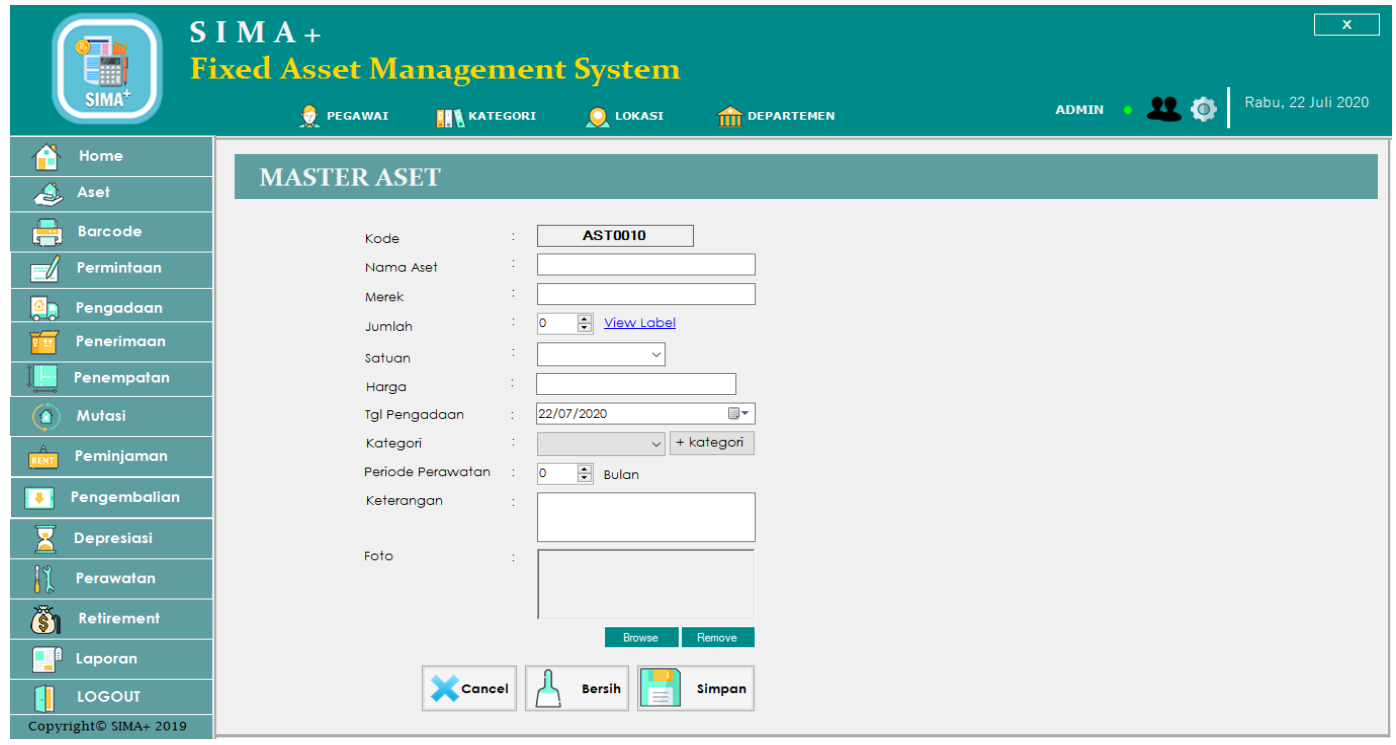

Gambar 10. Tampilan Master Data Aset Sistem Manajemen Aset SIMA ${ }^{+}$

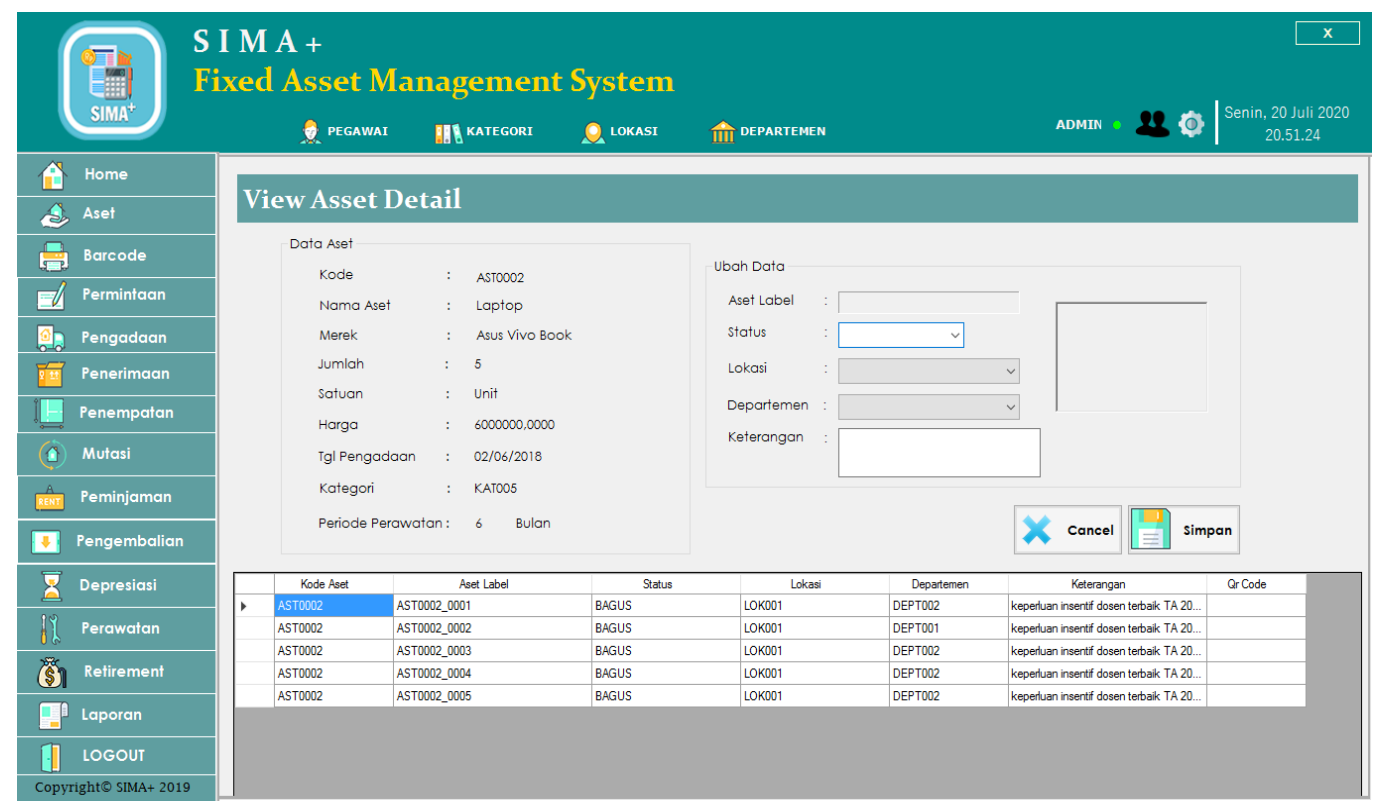

Gambar 11. Tampilan Sistem Menghasilkan Aset Label Secara Otomatis Manajemen Aset SIMA ${ }^{+}$ 
JURNAL MEDIA INFORMATIKA BUDIDARMA

Volume 5, Nomor 2, April 2021, Page 659-668

ISSN 2614-5278 (media cetak), ISSN 2548-8368 (media online)

Available Online at https://ejurnal.stmik-budidarma.ac.id/index.php/mib

DOI 10.30865/mib.v5i2.2663

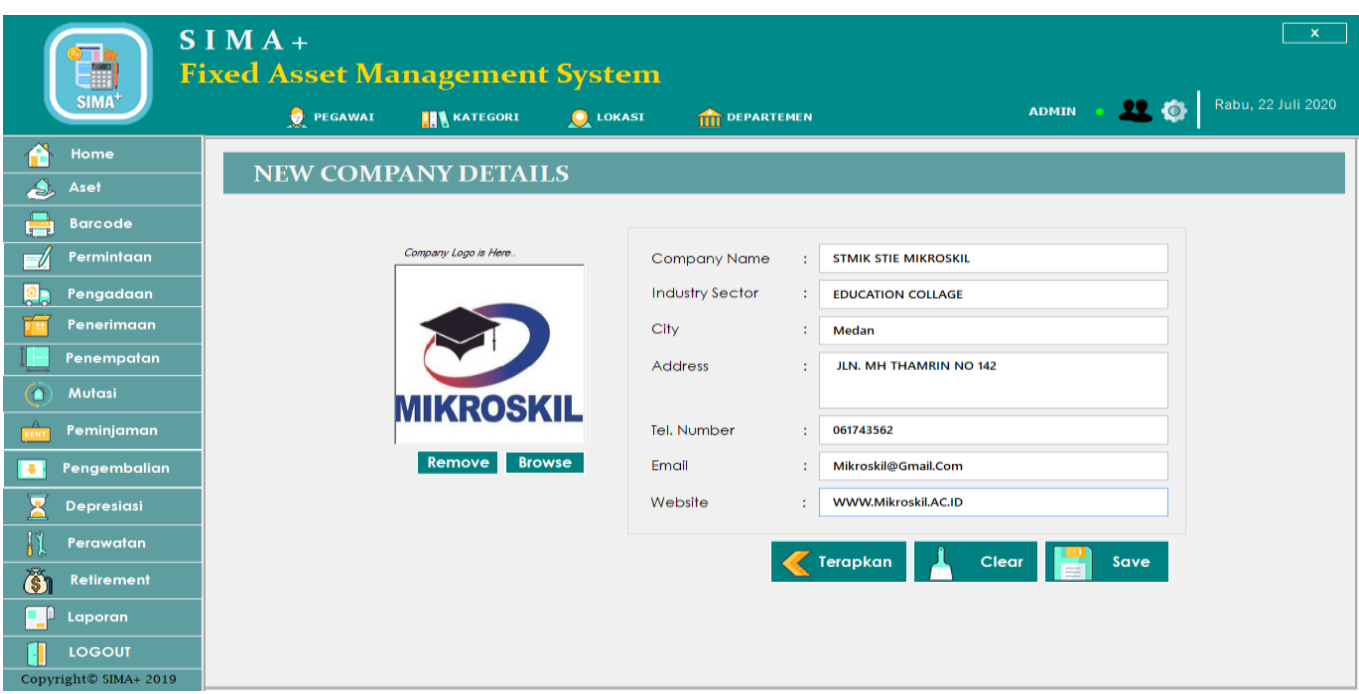

Gambar 12. Tampilan Master Profile Perusahaan Sistem Manajemen Aset SIMA ${ }^{+}$

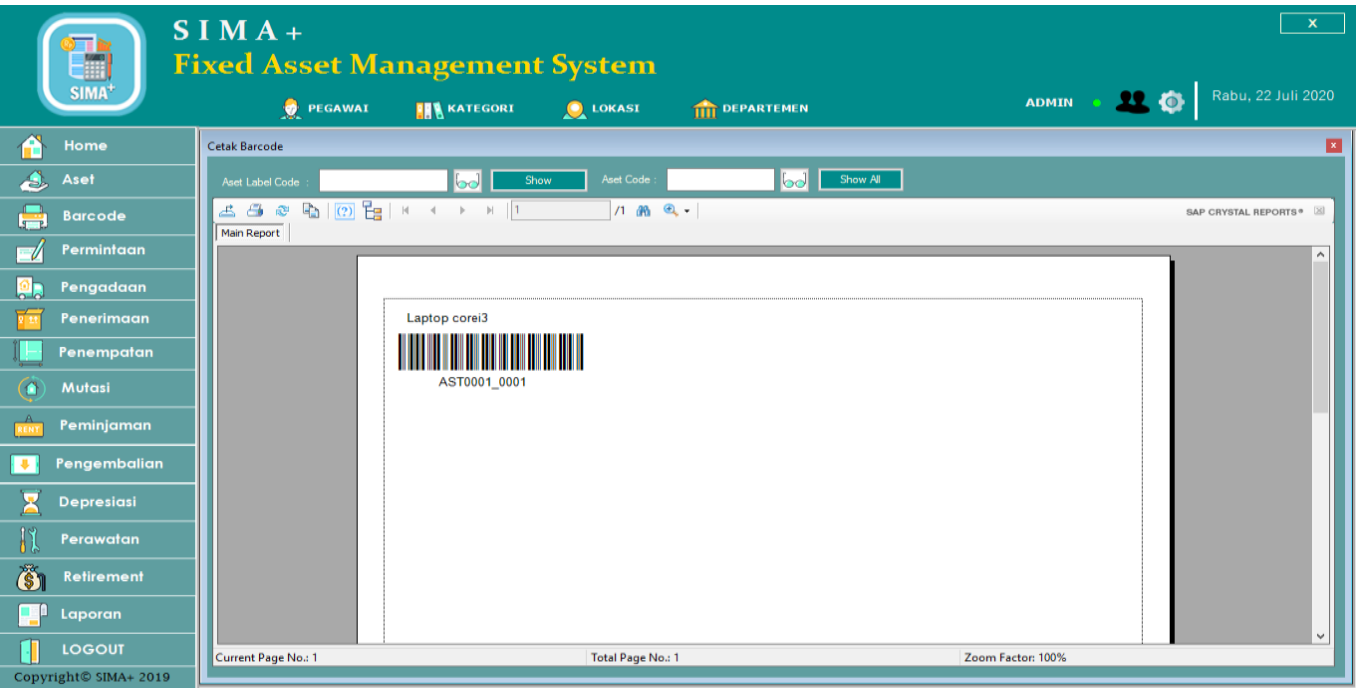

Gambar 13. Tampilan Cetak Barcode Aset Label Sistem Manajemen Aset SIMA ${ }^{+}$

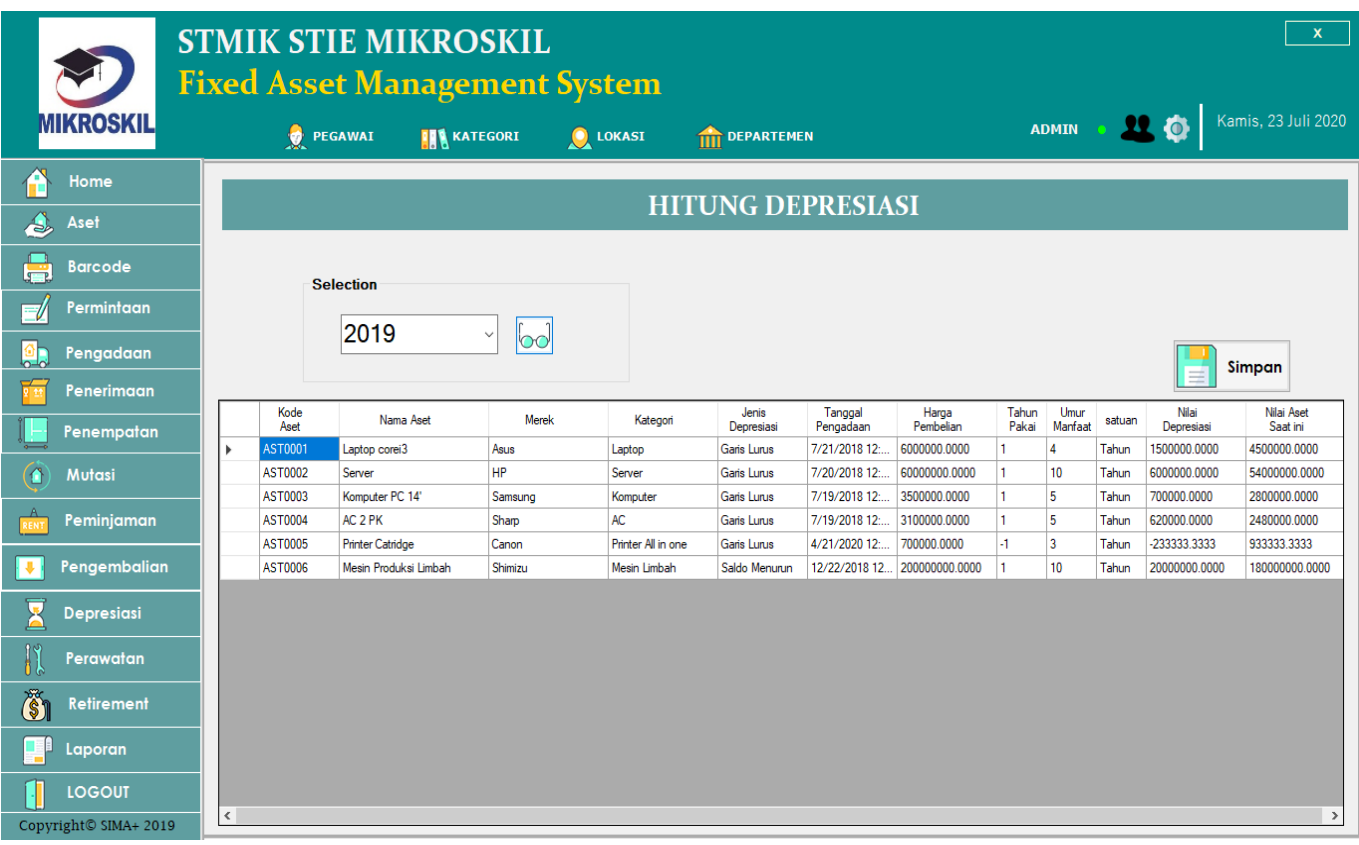

Gambar 14. Tampilan Proses Hitung Depresiasi Aset Sistem Manajemen Aset SIMA ${ }^{+}$ 


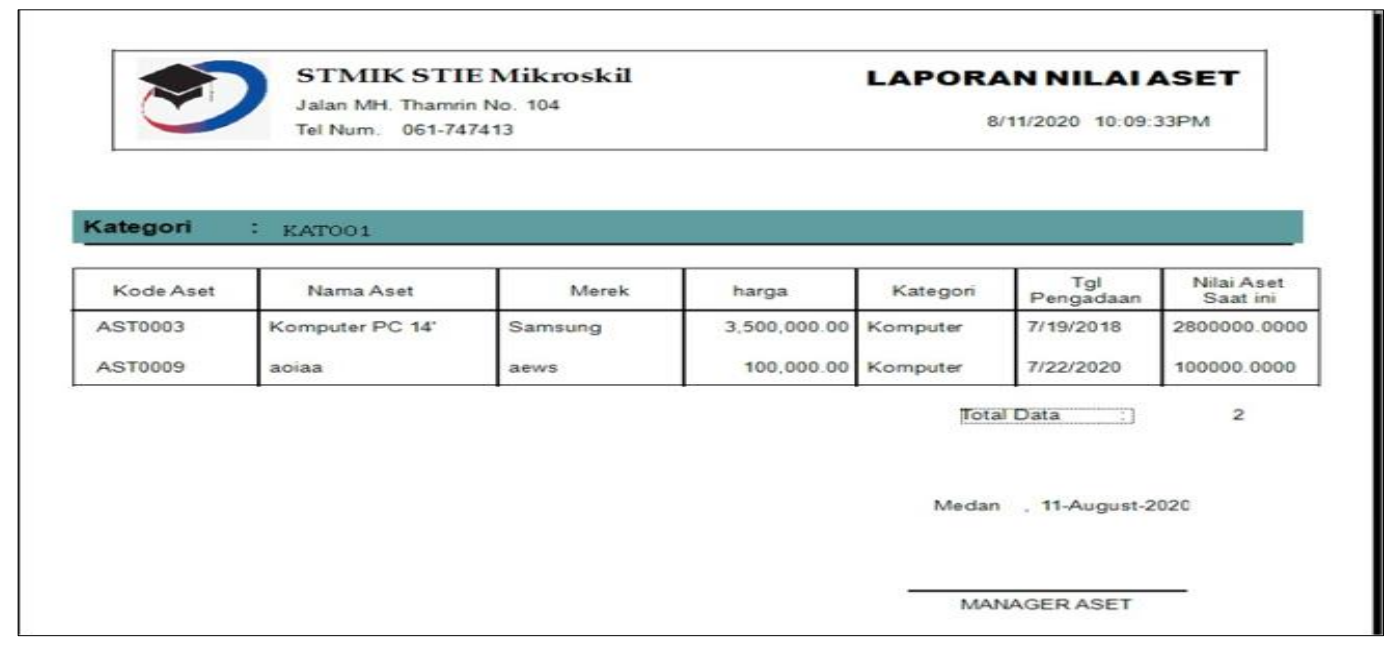

Gambar 15. Tampilan Laporan Nilai Aset Sistem Manajemen Aset SIMA ${ }^{+}$

\section{KESIMPULAN}

Berdasarkan tahapan-tahapan pengembangan sistem yang telah dilaksanakan dalam penelitian ini, maka dapat disimpulkan bahwa sistem yang diusulkan dapat digunakan oleh banyak perusahaan untuk membantu mempermudah proses manajemen aset, meminimalisir kesalahan transaksi pemanfaatan aset dan dapat menyesuaikan data aset yang tercatat pada sistem dan data aset secara fisik. Karena di dalam sistem ini terdapat form input profil perusahaan dan data ini yang akan digunakan untuk header laporan yang dihasilkan oleh sistem. Sistem yang diusulkan dapat memenuhi kebutuhan perusahaan untuk melakukan perhitungan depresiasi dengan berbagai metode perhitungan penyusutan sesuai dengan kategori aset yang dimiliki perusahaan. Sistem yang diusulkan dapat melakukan tugas yang lebih baik seperti reminder perawatan, persetujuan manajer atas permintaan dan perbaikan aset, upload foto aset dan penyempurnaan pada beberapa transaksi sehingga keamanan aset, nilai manfaat aset, dan umur penggunaan aset dapat maksimal. Untuk penelitian selanjutnya, diharapkan agar sistem dapat dikembangkan dengan penyimpanan data berbasis cloud serta sistem dapat dilengkapi dengan fitur yang lebih kompleks lagi tentang aset, seperti perhitungan yang dapat membantu penentuan keputusan tentang investasi aset pada perusahaan.

\section{REFERENCES}

[1] G. Ikhsan, D. S. Rusdianto and L. Fanani, "Pengembangan Sistem Manajemen Aset (Studi Kasus: RSUD dr. Iskak Tulungagung)," Jurnal Pengembangan Teknologi Informasi dan Ilmu Komputer, vol. 3, no. 7, pp. 6654-6661, 2019.

[2] I. Yunita and J. Devitra, "Analisis dan Perancangan Sistem Informasi Manajemen Aset Pada SMK Negeri 4 Kota Jambi," Jurnal Manajemen Sistem Informasi, vol. 2, no. 1, pp. 278-294, 2017.

[3] R. Amrullah, A. Megayanti and A. Yusta, "Sistem Informasi Manajemen Asset Berbasis Web (Studi Kasus: PT. Krakatau IT Cilegon)," Jurnal Sains dan Teknologi, vol. 4, no. 2, pp. 109-121, 2020.

[4] S. Dewi, L. M. Jannah and Y. Jumaryadi, "Analisis dan Perancangan Sistem Informasi Manajemen Aset Tetap Pada PT. Metis Teknologi Corporindo," Jurnal Sistem Informasi, Teknologi Informatika dan Komputer, vol. 9, no. 1, pp. 81-91, 2018.

[5] G. S. Pambudi, Sriyanto and A. Arvianto, "Rancang Bangun Sistem Informasi Manajemen Aset Berbasis Web Untuk Optimalisasi Penelusuran Aset Di Teknik Industri Undip," Jurnal Teknik Industri, vol. XI, no. 3, pp. 187-196, 2016.

[6] F. Fatma and J. Devitra, "Analisis dan Perancangan Sistem Informasi Manajemen Aset Berbasis Website Pada Biro Pengelolaan Barang Milik Daerah Setda Provinsi Jambi," Jurnal Manajemen Sistem Informasi, vol. 4, no. 1, pp. 28-37, 2019.

[7] A. Azahra, S. P. Raflesia and D. Lestarini, "Pengembangan Sistem Informasi Manajemen Aset Pada PT. X," Generic, vol. 12 , no. 2 , pp. 38-45, 2020.

[8] M. Ridwan, Muhammad and S. Ramadhani, "Rancang Sistem Informasi Manajemen Aset di PT. Sentral Tukang Indonesia," Jurnal CoreIT, vol. 3, no. 2, pp. 47-53, 2017.

[9] A. Susanto, Sistem Informasi Manajemen: Konsep dan Pengembangannya Secara Terpadu, Bandung: Lingga Jaya, 2017.

[10] S. D. Purnamasari and F. Panjaitan, "Pengembangan Aplikasi E-Reporting Kerusakan Lampu Jalan Berbasis Mobile," Jurnal Sistem Komputer Musirawas, vol. 5, no. 1, pp. 59-69, 2020.

[11] E. Y. Anggraeni and R. Irviani, Pengantar Sistem Informasi Menggunakan Model Terstruktur dan UML. Yogyakarta: Andi, 2017.

[12] Kendall Kenneth E, ANALISIS DAN PERANCANGAN SISTEM. INDEKS, 2006.

[13] A. Nugroho, Rekayasa Perangkat Lunak Menggunkan UML dan Java. Yogyakarta: Andi Offset, 2009.

[14] M. S. Rossa A.S, Rekayasa Perangkat Lunak. Informatika Bandung, 2016.

[15] J. Simarmata, Rekayasa Perangkat Lunak. Yogyakarta: Andi, 2010. 